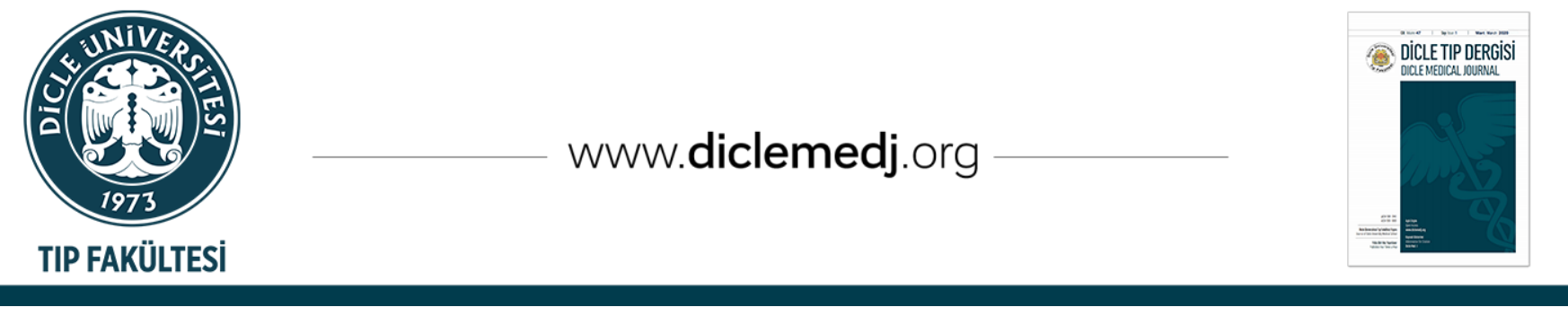

Case Report / Olgu Sunumu

\title{
A Sarcoidosis Case With Galaxy Sign Admitted With A Rare Symptom : Hemoptysis
}

\author{
Lale Sertçelik iD 1, Fatma Armağan Hazar (iD) 1 , İpek Erdem (D) 1 , Aylin Güngör iD 2 \\ 1 University of Health Sciences Istanbul Sureyyapasa Chest Diseases and Thoracic Surgery Research and Training Hospital, Turkey \\ 2 Dokuz Eylul University Faculty of Medicine, Occupational Medicine Clinic, Izmir, Turkey
}

Received: 25.07.2019; Revised: 31.12.2020; Accepted: 22.01.2020

\begin{abstract}
30 year-old male patient applied to hospital with complaint of hemoptysis. 30 year-old male patient applied to hospital with complaint of hemoptysis. Bilateral extensive nodular infiltrations and mediastinal lymphadenopathies were detected. Wedge resection and parietal pleura biopsy were performed for the patient. The pathology report indicated that the case should be further examined from the aspect of granulomatous diseases, especially the sarcoidosis. The diagnosis was made as galaxy sign of sarcoidosis. Hemoptysis is a rare symptom seen in sarcoidosis. The hemoptysis is observed at advanced stage of sarcoidosis and in presence of cavity in sarcoidosis. There is no study in literature regarding the initial complaint of hemoptysis in sarcoidosis case, for whom the galaxy appearance was observed radiologically. Here, we present the etiological causes of granulomatous inflammation in sarcoidosis with non-typical clinic and radiology.
\end{abstract}

Keyword: Sarcoidosis, hemoptysis, sarcoid galaxy sing, granulomatous inflammation

DOI: 10.5798/dicletip.755779

Correspondence / Yazışma Adresi: Lale Sertçelik, University of Health Sciences Istanbul Sureyyapasa Chest Diseases and Thoracic Surgery Research and Training Hospital, Istanbul, Turkey e-mail: lalesertcelik@gmail.com 


\section{Galaksi Bulgusu Olan Sarkoidozlu Bir Olguda Nadir Bir Semptom: Hemoptizi}

\section{$\ddot{0} \mathbf{z}$}

Sarkoidoz nedeni bilinmeyen granülomatöz inflamasyona neden olan sistemik bir hastalıktır. Burada 30 yaşında hemoptizi ile hastanemize başvuran bir erkek hasta sunulmuştur. Multıpl mediastinal lapları ve akciğer parankiminde nodülleri saptanmıștır.Yapılan wedge rezeksiyon ve parietal plevra biyopsi sonucu granülomatöz hastalıklar açısından ayırıcı tanısı yapılmalıdır olarak raporlandı. Klinik ve radyolojik bulgularla birlikte değerlendirildiğinde tanı sarkoidoz-galaksi bulgusu olarak kondu. Hemoptizi sarkoidozda nadir görülen bir semptomdur. İleri evre ve kaviter sarkoidozda görülür. Vakamızda ileri evre ve kaviter sarkoidoz bulguları olmamasına rağmen başvuru şikayeti hemoptizidir.

Anahtar kelimeler: Sarcoidosis; hemoptysis; 'sarcoid galaxy’ sign; granulomatous inflammation.

\section{INTRODUCTION}

The sarcoidosis is a granulomatous disease, the reason of which is not known. It is seen in all the races, age groups in both genders throughout the world. But, the prevalence, involvement types, severity, and clinical course of disease vary between the societies. According to an access study, the involvement rates were found to be $95 \%$ for lungs, $15.9 \%$ for skin (erythema nodosum), $15.2 \%$ for lymph node, and $11.8 \%$ for eyes ${ }^{1,2}$.

In pathology of the disease, the noncaseating granolomatos are used in diagnosis. Sometimes, the granulomas might contain focal coagulation necrosis. The epithelium cells, lymphocytes, fibroblasts, large Langerhans cells are observed in pathology. These granulomas might disappear or course towards fibrosis throughout the prognosis of disease $\mathrm{e}^{1,2}$.

Although there are various opinions regarding the etiology, the inflammatory reaction develops most likely as a result of exposure of patients, who have possible genetic disposition, to various environmental factors ${ }^{1,2}$.

Sarcoidosis is observed together with coughing, difficulty in breathing, fatigue, night sweating, chest pain, weight loss, and rarely hemoptysis. The hemoptysis is observed at advanced stage of sarcoidosis and in presence of cavity ${ }^{3-6}$. Here, it was aimed to represent a sarcoidosis case, who applied with hemoptysis but showed the radiological characteristics of galaxy findings.

\section{CASE PRESENTATION}

30 year-old male patient applied to hospital with complaint of hemoptysis. It was learnt that the patient had approx. 1 tea glass of bloody phlegm 1 week ago and the situation occurred several times. The hemoptysis was accompanied by fever and night sweating. In PA chest radiography, nodular lesions, the largest of which was on left bottom zone, were observed in bilateral lung parenchyma, and then the thoracic CT was taken. (Figure 1)

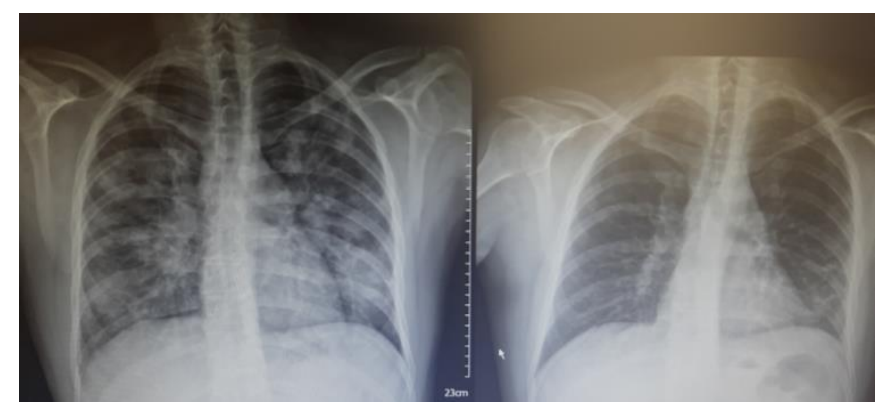

Figüre 1: Pre and post treatment Chest $X$ Ray

Bilateral extensive nodular infiltrations and mediastinal lymphadenopathies (lap) were detected.(Figure 2,3) Fiber-optic bronchoscopy (fob) was performed, no endobronchial lesion was observed, and minimal hemoptysis in trachea and bright red hemorrhage from leftbottom lob superior segment were observed. The patient was referred to our hospital for endobronchial ultrasonography (EBUS) because he had mediastinal laps. In his history, the patient has used salazopryl 2-3 years before because of ankylosing spondylitis and he used to smoke 8 packages per year (active smoker). 


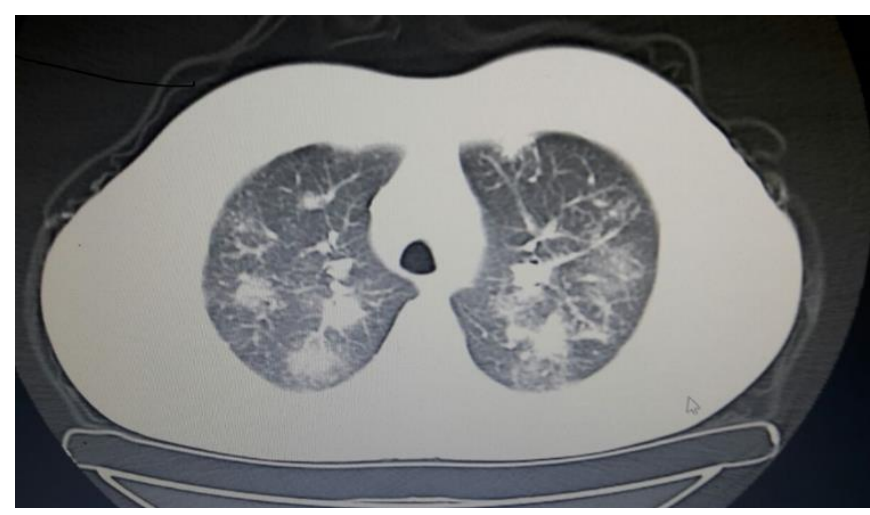

Figüre 2: Thorax CT image 1

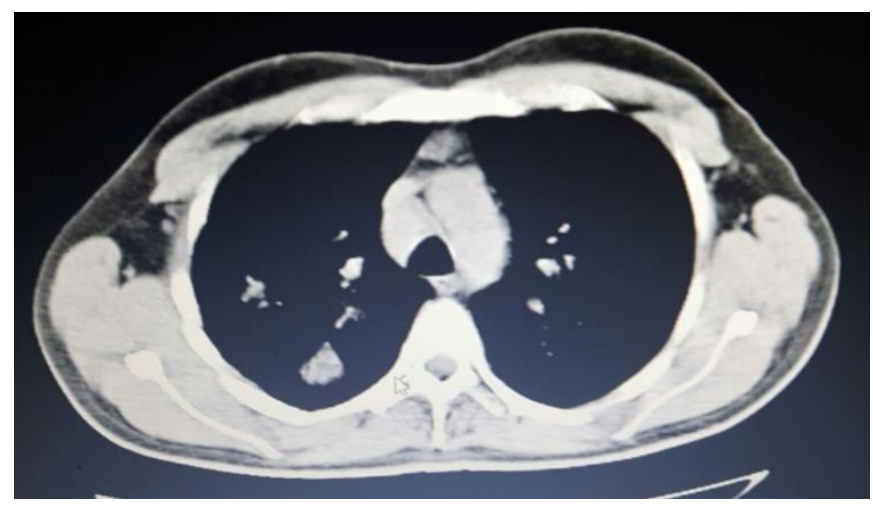

Figüre 3: Thorax CT image 2

In family history, his father has been followed up with diagnosis of multiple myeloma. The physical examination findings were as follows; arteriyel blood pressure was 120/90 $\mathrm{mmHg}$, heart rate was $90 \mathrm{bpm}$, fever was $36.5^{\circ} \mathrm{C}$, respiratory rate was $12 / \mathrm{min}$, oxygen saturation was 97 (at room temperature), and the systemic examination findings were normal. Based on the current findings, the metastatic lung disease (testicle carcinoma ?, lung metastasis?), tuberculosis, sarcoidosis, collagen tissue diseases (Wegener granulomatosis ?), lung involvement, and lymphoma provisional diagnoses were examined. The hemogram, biochemical, PT, and APTT findings were normal. ESH was found to be $33 \mathrm{~mm} / \mathrm{h}$, whereas CRP was 23, which is mildly high. Blood ACE level was determined to be $109 \mathrm{u} / \mathrm{l}(0-45 \mathrm{u} / \mathrm{l})$. ARB results of 2 phlegm specimens were negative. Phlegm PCR was negative. The findings obtained from complete abdomen, urinary system, and scrotal US were within normal limits, and there was no proteinuria or hematuria. The findings regarding entire abdomen, urinary system, and scrotum were within the normal limits, no mass lesion was observed. Otorhinolaryngology consultation was requested, the findings were within normal limits. Markers were requested for diagnosing the collagen vascular diseases. Eye consultation was requested for examining the organ involvement of sarcoidosis, and no uveitis was detected. A cardiologist performed an examination, the echocardiography results were within the normal limits. Since the EBUS device was out of order, the patient was unable to perform ebus. The patient was discussed in sarcoidosis council. It was decided to perform a diagnostic surgery (mediastinascopy or wedge resection).

The patient was then referred to surgery department. PET-CT was performed due to suspected lung cancer, lymphoma, and metastatic lung disease because he applied with hemoptysis and he had extensive infiltrations in lung parenchyma and multiple mediastinal laps. In both sides of the lung, multiple dispersed massive and nodular lesions having irregular margins and reaching up to $40 \times 39 \mathrm{~mm}$ in dimensions were observed. Sud max was observed to be 8.9 in these lesions, whereas it was reported to be 4.0 in infiltration zones having icy glass appearance. The lymphadenopathies having conglomerated appearance, the largest one of which was $3 \mathrm{~cm}$ in diameter in subcarinal zone, were observed in mediastinum, bilateral upper mediastinal, right top-bottom paratracheal, left bottom paratracheal, paraaortic, aorticopulmonary window, and bilateral hilar- interlobar zones. SUD max was observed to be 7.0 for these lymphadenopathies. The craniocaudal diameter of spleen was measured as $135 \mathrm{~mm}$. In f18-fdg uptake, there was a remarkable increase in spleen when compared to liver. (spleen sud max: 4.8/liver sud max: 4.5) The laps were 
observed in a couple of lymphadenopathies at I1 vertebra level in precaval zone and peripancreatic zone (largest one having $17 \mathrm{~mm}$ diameter). SUD max of these laps was determined to be 5.3. Moreover, a couple of nodular lesions, the largest of which is $11 \mathrm{~mm}$ in diameter at the mesenteric fatty tissues, were observed at 14 vertebra level in the right bowel zone. SUD max was observed to be 2.2. (Figure 4).

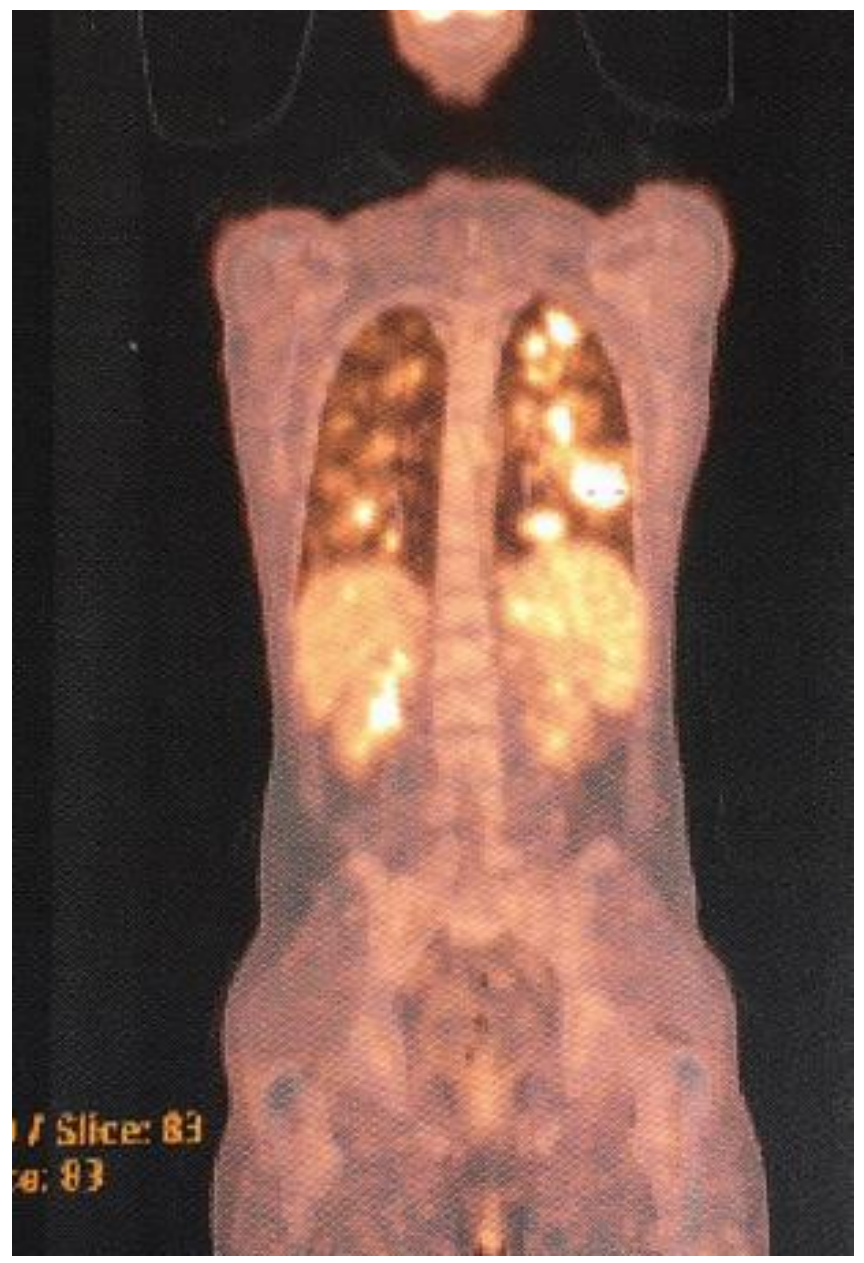

Figüre 4: Pet-Ct image

Wedge resection and parietal pleura biopsy were performed for the patient. The pathology report indicated that the case should be further examined from the aspect of granulomatous diseases, especially the sarcoidosis.

The diagnosis was made as galaxy sign of sarcoidosis.
The patient was given sft, dlco. Fev1/fvc: 95 fev1: 2.29 (41\%), fvc: 2.18 (47\%), fev1/fvc: $91 \%$, and dlco: $77 \%$. The patient was given treatment with $40 \mathrm{mg} /$ day methylprednisolone. During the examinations at the end of 3 months, the results were as follows; fev1: $3.02(66 \%)$, fvc: $3.30(60 \%)$, and dlco: $54 \%$. Almost complete regression was observed in PA radiography. The dose of methylprednisolone was reduced to $12 \mathrm{mg} /$ day, and stopped.

\section{DISCUSSION}

The granulomatous inflammatory diseases should be considered in differential diagnosis of sarcoidosis. Pneumoconiosis, tuberculosis, lymphoma, berylliosis, autoimmune collagen vascular diseases with interstitial vasculitis, eosinophilic granuloma, drug reactions, lung cancer, lymphangitis carcinomatosis, fungal infections, brucellosis, kikuchi disease, cat scratch (benign lymphoreticulosis), primary biliary cirrhosis, schistosomiasis, chron disease, and glus syndromes (granulomatous lesion with unknown importance) should be considered in differential diagnosis ${ }^{1,2}$.

The case might be clinically asymptomatic. Fever, asthenia, quick fatigue, weight loss, night sweating, chest pain, exertional dyspnea, and cough might be observed ${ }^{1,2}$. The hemoptysis is a rare symptom seen in sarcoidosis, for which our case applied to our hospital. It is generally observed in advanced sarcoidosis and in cases accompanied with cavity. But, also the sarcoidosis cases have been reported before the fibrosis and exceeding beyond cavity. It might be severe and lethal ${ }^{3-6}$.

Since our case applied with complaint of hemoptysis and extensive nodular infiltrations were observed in chest radiography, Wegener granulomatosis was taken into consideration. The collagen vascular markers were examined, and the results were negative. No hematuria was detected in complete urine analysis. For these reasons, Wegener granulomatosis 
diagnosis was excluded from the list. The results obtained from scrotal US, which was performed because another provisional diagnosis was metastatic lung disease (testicle carcinoma?), were within the normal limits. PET-CT was performed, but no results indicating a metastasis from another organ was obtained. For this reason, the provisional diagnosis of metastatic lung disease was removed from the list6-8.

Our case was examined based on the current findings, and the diagnostic surgery decision was made. Wedge resection and parietal pleura biopsy were performed. Pathology results indicated that the case should be further examined from the aspect of granulomatous diseases (especially the sarcoidosis).

Based on the current findings, the symptoms were considered as galaxy symptoms of sarcoidosis. He was 5th galaxy symptom followed in sarcoidosis polyclinic of our hospital.

The radiological symptoms of sarcoidosis are grouped as typical and atypical ones. The typical symptoms are bilateral, symmetric, hilar, and right paratracheal lap, bilateral hilar lap without accompanying mediastinal lap, perilymphatically diffuse micronodules, linear opacities, traction bronchiectasis, and structural deformities especially in upper and medial zones. The atypical radiological symptoms are asymmetrically located laps observed in unexpected zones (internal mammarial chain, paravertebral, and retrocrural zone), perihilar and peripherically located pulmonary nodules, air bronchograms, cavity (rarely), mass, solitary pulmonary nodule, galaxy symptom, patched icy glass appearances, linear reticular opacities, miliary pattern, airway involvement, mosaic pattern, air trapping, bronchiectasis, stenosis, atelectasis, endobronchial mass, pleural fluid, hemothorax, cheilothorax, pneumothorax, pleural thickening, and (rarely) pleural calcification ${ }^{9}$.

The galaxy symptom has been defined in a publication prepared in Japan in year 2002. These are the formations observed in thoracic computed tomography and consisting of the unification of numerous granulomas, and they have irregular margins. They are seen in form of nodules involving low-density zones. The nodules larger than $10 \mathrm{~mm}$ can be seen in pulmonary tuberculosis, lung cancer, and progressive massive fibrosis, in addition to the sarcoidosis. But, when the galaxy symptom is detected, pulmonary sarcoidosis should be primarily taken into consideration ${ }^{10,11}$.

One of the most frequently experienced difficulties in making the differential diagnosis in pulmonary diseases is the patients, pathology of whom indicates the granulomatous lung diseases.

The point that should be taken into consideration during differential diagnosis is the diseases with various treatment and prognosis such as lymphoma, vasculitis, sarcoidosis, and tuberculosis. For this reason, it is very important to make the diagnosis accurately.

Hemoptysis is a rare symptom seen in sarcoidosis. It is observed generally in advanced stage of sarcoidosis and in cases, in which cavity is observed radiologically. There is no study in literature regarding the initial complaint of hemoptysis in sarcoidosis case, for whom the galaxy appearance was observed radiologically. Here, we present the etiological causes of granulomatous inflammation in sarcoidosis with non-typical clinic and radiology.

Informed Voluntary Consent Form: Consent form was taken from the patient.

Declaration of conflicting Interest: The authors declare that have noconclift of interest. 
Financial Disclosure: No financial support was received.

\section{REFERENCES}

1. Tabak L, Kumbasar Ö Ö, Diffüz Parankimal Akciğer Hastalıkları, 1.baskl, Ankara, Toraks Derneği, Mayıs 2013; p 75-97.

2. Özlü T, Metintaş M, Karadağ M, Kaya A, Sarkoidoz, Solunum Sistemi ve Hastalıkları, 1. Baskı, Ankara, İstanbul Medikal Yayıncıllk, 2010; p.1101-12.

3. Lemay V, Caretta MF, Parrot A, et al. Hemoptysis in Sarcoidoisis. Apropos of 6 cases including 4 with fata outcome. Rev Pneumol Clin. 1995; 51: 61-70.

4. Subroto P, Andrews W, Nasar A, et al. Prevalence and Outcome of Anatomic Lung Resection for Hemoptysis: An Analysis of Nationwide Inpatient Sample Database. Ann Thorac Surg. 2013;96:391-8.

5. Sharma OP. Fatigue and Sarcoidosis. Eur Respir J. 1999; 13: 713.
6. Badri F, Batahar SA, Idrissi SE, et al.Pleuropulmonary Metastases Originating From Extra-Thoracic Neoplasia. Pan Afr Med Journal. 2017; 30: 26: 44.

7. Judson MA, MD, The Dİagnosis of Sarcoidosis. Clin Chest Med. 2008; 29: 415-27.

8. Quadrelli S, Dubinksy D, Solis M, et al. Immun Diffuse Alveolar Hemorrhage: Clinical Presentation and Outcome. Respiratory Medicine 2017; 129: 59-62.

9. www. myERS.org/ecr2013/C-0169.

10. Nakatsu M, Hatabu H, Morikawa K. Large. Coalescent Parenchymal Nodules in Pulmonary Sarcoidosis: "Sarcoid Galaxy" Sign. AJR Am J Roentgenol. 2002 Jun; 178: 1389-93.

11. Koide $\mathrm{T}$, Takeshi $\mathrm{S}$, Tsukahara $\mathrm{Y}$, et al. Clinical Signifiance of The 'Galaxy Sign' in Patient with Pulmonary Sarcoidosis In A Japanase-Center Cohort. Sarcodidosis Vascular Diffuse Lung Dis. 2016; 33: 247-52. 